УДК 378.016:781.62

\title{
МЕЛОДИЧНИЙ СЛУХ ЯК БАЗОВА ЗДІБНІСТЬ У ПРОЦЕСІ ФОРМУВАННЯ МУЗИЧНО-ІНТОНАЦІЙНОГО МИСЛЕННЯ
}

\author{
Спіліоті О. В.
}

У статті розкривається проблема значущості такої базової здібності, як мелодичний слух, у процесі формування музично-інтонаційного мислення. Проаналізовані різні теоретико-методологічні підходи до розвитку мелодичного слуху. Наголошується, що наявність його відіграє важливу роль у музичнотворчій діяльності. Доводиться, що розвинутість мелодичного слуху прямо залежить від наявності внутрішнього слуху, а саме здібності передчувати звучання, оперувати музично-слуховими уявленнями. Завдяки внутрішньому слуху музиканти подумки уявляють звучання твору до його виконання, а також під час виконання, що дозволяє контролювати реальне звучання.

Ключові слова: мелодичний слух, чуття ладу, музично-інтонаційне мислення.

В статье раскрывается проблема значимости такой базовой способности, как мелодический слух, в процессе формирования музыкально-интонационного мышления. Проанализированы разные теоретико-методологические подходы, что касается развития мелодического слуха. Акцентируется, что его наличие играет большую роль в музыкально-творческой деятельности. Доказывается, что мелодический слух напрямую зависит от наличия внутреннего слуха, а именно способности предчувствовать звучание, оперировать музыкальнослуховыми представлениями. Благодаря внутреннему слуху музыканты мысленно представляют звучание произедения до его исполнения, а также во время исполнения, позволяет контролировать реальное звучание.

Ключевые слова: мелодический слух, чувства лада, музыкально-интонационное мышление.

The article highlights the problem of the significance of such basic skills as melodic hearing in the musical intonation thinking. Analyzed various theoretical and methodological approaches to the development of melodic hearing. It showed how this sense is important in music teaching and creative activities.

Analyzing the formation of musical intonation thinking most researchers focusing primarily on its individual components (perception, reflection, creativity). They prove their priority in the process of thinking. However, the complex mechanism of musical thinking could not exist without some basic music skills, such as melodic hearing (intonation hearing), sense of rhythm and memory.

In the process of musical intonation thought advisable to rely on the methodical provisions on melodic development of intonation hearing. Among them: education system and sense modal connections sounds; learning and auditory representations fixing elements of musical language; formation good singers skills; ability to operate hearing ideas for using them in singing; ability to listen and assess the quality of singing. It is proved that developed intonation hearing depends on the availability of internal hearing, the ability to anticipate sound, music and operate auditory representations. Due to the internal hearing musicians represent mentally sound before performance, and during performance, which allows to control the actual sound. Key words: melodic hearing, sense of mode, musical intonation thinking.

Завдання, поставлені перед сучасною школою, вимагають відповідних змін у професійній підготовці вчителів, зокрема учителів музики. Їх освітній потенціал має бути фундаментальним, збагачуватися шляхом засвоєння музично-теоретичних знань і виконавських умінь. У процесі становлення особистості майбутнього вчителя музики вагоме місце посідає формування його музично-інтонаційного мислення, яке, будучи важливою складовою музичних здібностей, визначає успішність художнього пізнання, суттєво позначається на якості музично-творчої діяльності. 
Аналізуючи проблематику формування музично-інтонаційного мислення, більшість дослідників концентрує свою увагу здебільшого на окремих його компонентах (сприймання, рефлексія, творчість), доводячи їх пріоритетність у процесі мислення. Однак складний механізм музичного мислення не може існувати без наявності базових професійних здібностей, а саме мелодичного слуху (інтонаційного слуху), чуття ритму та пам'яті.

Мета статті полягає у розкритті значущості такої базової здібності, як мелодичний слух, який безпосередньо задіяний у процесі формування музичноінтонаційного мислення.

У процесі формування музично-інтонаційного мислення доцільно спиратися на методичні положення щодо розвитку мелодичного слуху (інтонаційного слуху), а саме: виховання чуття ладу та ладових зв'язків звуків; вивчення та закріплення слухових уявлень елементів музичної мови; формування правильних співацьких навичок; уміння оперувати слуховими уявленнями для використання їх у співі; уміння слухати та оцінювати якість співу [5, с. 62].

Інтонаційний слух - важливий компонент музичних здібностей. Його властивість - це здатність сприймати, запам'ятовувати звуки різної висоти. Однак йдеться не про розвиток абсолютного слуху. Головне - приділяти велике значення засвоєнню зв'язків звуків, мелодії. Отже, у процесі формування музично-інтонаційного мислення слід розвивати мелодичний слух, а саме здібність сприймати, запам'ятовувати та відтворювати мелодію. Під час роботи над мелодичним слухом інтонація розуміється як мелодичний зворот і як точність та чистота звучання. Дотримуючись порад О. Давидової, бажано акцентувати увагу на взаємозв'язку цих значень та значущості їх урахування в роботі над розвитком слуху.

Б. Теплов підкреслював, що не можна прагнути розвивати відчуття музичної висоти, тобто сенсорну базу музичного слуху, починаючи роботу над окремими інтервалами. Вчений пропонує зосередитися на роботі над мелодіями, особливо такими, які дають можливість яскраво переживати ладові відношення.

Робота над розвитком чуття ладу повинна здійснюватися протягом усього музичного навчання. Звертаючись до методичних порад вітчизняних педагогів, формування ладового чуття має бути поетапним. Так, перший етап - виховання чуття тональної стійкості, вміння зберігати тональність, чуття тональної перспективи, тобто - засвоїти діатоніку на будь-якій висоті. Другий етап - виховання здібності долати діатоніку, тобто засвоєння альтерації ступенів, хроматичних прохідних та допоміжних звуків у межах відповідної тональності. Слід виокремити виховання здібності слухової перебудови, тобто вміння переосмислювати звук відповідної тональності у нову.

Рівень розвитку мелодичного слуху залежить від точного інтонування мелодії. Працюючи над чистим інтонуванням, слід звернути увагу на внутрішні музичні уявлення та на голосовий апарат. Розвиваючи мелодичний та інтонаційний слух, ми звертаємося до слухових та співацьких рефлексів.

Розвинутість інтонаційного слуху прямо залежить від наявності внутрішнього слуху, а саме здібності передчувати звучання, оперувати музично-слуховими уявленнями. Завдяки внутрішньому слуху музиканти подумки уявляють звучання твору до його виконання, а також під час виконання, що дозволяє контролювати реальне звучання. Цьому феномену надають великого значення музиканти, психологи, педагоги. Так, Б. Теплов підкреслював: "Внутрішній слух ми повинні визначити... не просто як здібність уявляти собі музичні звуки, а й як здібність за власним бажанням оперувати музичними, слуховими уявленнями" [7, с. 174].

Серед методів фрормування та розвитку внутрішнього слуху зорієнтуємося на основних: підбір музики на слух (цей вид діяльності вимагає від виконавця ясних та чітких слухових уявлень); виконання твору (навчального репертуару) в повільному темпі з налаштуванням на передчуття наступного розгортання музики; виконання музичного твору засобом "пунктиру" (одну - фраза "вголос", другу - "подумки", зберігаючи злиття звукового руху); беззвучна гра на інструменті; прослухування маловідомих творів зі стеженням за нотним текстом; засвоєння музичного матеріалу шляхом заглиблення в його виразну сутність через виконання подумки з нот; вивчення напам'ять завдяки музикуванню подумки з нот [8, с. 78-79]. 
Внутрішній слух Б. Яворський вважав найважливішим, оскільки він слугує основою музичного мислення. "Внутрішній слух надає музиканту-виконавцю: здатність швидко орієнтуватися у творі, осягати його в цілому, уявити співвідношення частин, розділів, оперувати музичними уявленнями, подумки створювати чіткий конкретний виконавський план, який мобілізує волю музиканта, керує вибором необхідних засобів втілення. 3 накопиченням досвіду на базі внутрішнього слуху відбувається фрормування музичного мислення" [2, с. 54]. За класифікацією Б. Яворського, музичний слух поділяється на такі різновиди: слух строю - відчуття правильності співвідношення; слух ладу - здатність установити устої та неустої в межах музичних систем та взаємовідношення систем; слух часовий; архітектонічний слух; чуття логіки.

Серед форм педагогічної роботи з розвитку слуху та музичного мислення Б. Яворський рекомендував і запроваджував у навчальному процесі для музикантів усіх спеціальностей спів у хорі, диригування хором, сольфеджування гармонічних схем (яке формує логіку голосоведення та ладового тяжіння) i, головне, слухання музики.

Теоретичне вчення Б. Яворського має слухову спрямованість. Питання щодо виховання слуху вчений ставив широко. Організація слуху, на думку вченого, має єдине джерело походження: виховання певної культури слухового сприйняття, поява "внутрішнього слухового налаштування" [3, с. 136]. 3 поняття внутрішнього слухового налаштування Б. Яворський виокремлює якості слуху. Саме це він вважає опорою музичної свідомості та музичного мислення.

Термін ладове налаштування часто зустрічається в працях з методики сольфеджіо, а також у працях, які розглядають психологію музичного мислення та музичного слуху. Музичний процес для Б.Яворського - це простежування фрормування та фуннцііонування внутрішнього слухового налаштування, яке організовує мислення в процесі сприймання. Обов'язковою умовою внутрішнього слухового налаштування $€$ увага, яка може "встановити, безперервно утримувати й активно спрямовувати відповідне внутрішне слухове налаштування впродовж певного проміжку часу" [9, с. 9].

Б. Яворський розрізняє внутрішній слух - справжній, автентичний, музикантський, що характеризується самостійністю, активністю; та слух зовнішній стандартизований (пасивне сприймання, яке виховане на звичці перебудовувати слухову реакцію "на стандарт"). Учений вважав, що при зовнішньому слуху відбувається "сприймання окремих звичних і тому бажаних звукових моментів i відкидання небажаних... Внутрішнє налаштування не піддається новій організації звукових явищ" [9, с. 11]. Відповідно, в нормальній слуховій реакції здійснюються звичні асоціації, які заважають внутрішньому слуху вільно реагувати на вплив нового.

Музикознавець Ю. Бичков тлумачить поняття ладового налаштування як особливий психологічний механізм, який регулює процес осмислення та оцінки звукових елементів і формує з них ціле. Звукоряд, система устоїв та неустоїв, фрункціональна структура ладу створюють у нашій свідомості ладове поле (налаштування). Окремі звуки та мелодичні звороти, які потрапляють у ладове поле (при багатоголосному викладі - акорди та акордові послідовності) набувають ладової якості. Учений підкреслює, що включення налаштування у процес інтонування зумовлює їі постійну зміну, необхідність переналаштування. Залежно від ступеня індивідуалізації ладового процесу, настройка може бути інерційною (якщо воно випливає із закономірностей музичної мови) та ініціативним (якщо воно побудоване на особливостях конкретного процесу інтонування). Стійкість та нестійкість виявляються у ладі на різних рівнях [4].

Особливу увагу привертає до себе угорська релятивна система, створена 3. Кодаєм. Початковий етап будується на ритмічному вихованні та використовуванні ручних знаків. Найголовніше в цій системі те, що навчання починається 3 найпростіших мелодичних поспівок.

У сучасній музичній педагогіці подібного принципу дотримується методична система В.Брайніна. Музикант-педагог пропонує відразу ж учити невеличкі, не поділені на складові музичні думки. Це можуть бути два-три звуки, які об'єднуються 
певними ладовими та ритмічними відношеннями. Поспівки містять конкретну інтонаційну інформацію та створюють стилістичний контекст. Наприклад, мотив, який типовий для європейської музики, проспівується, програється:

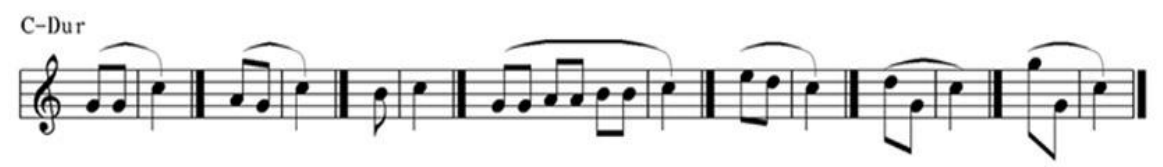

Цікаво те, що учень, не знаючи нот, засвоює ладові та ритмічні формули. У такий спосіб ці інтонації міцно осідають в його свідомості і перетворюються на зрозумілий образ. Далі процес навчання будується на поступовому засвоюванні основного інтонаційного фонду класики, романтики тощо [10].

У цьому зв'язку можна згадати методологічні принципи Л. Робустової. Теоретик звертається до мовної та музичної інтонації, підкреслюючи походження і єдність понять. У педагогічному аспекті до цього питання звертався Б. Асаф'єв, пропонуючи як один із прийомів роботи "музичне читання". Наслідуючи його ідеї, Л. Робустова підкреслює, що "найбільш доступним для музичного сприймання дитини є інтонації біогенного типу (тобто інтонації стогону, виклику, запитання тощо). Ці інтонації посідають чільне місце у словесному лексиконі людини" [6, с. 244];

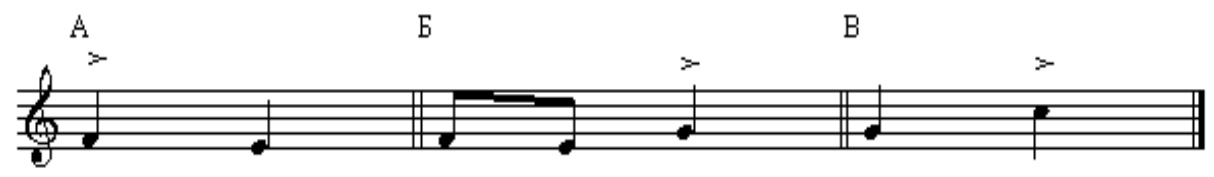

Музичні еквіваленти інтонації стогону (А), запитання (Б), ствердження або виклику (В).

Прості ладові структури повинні засвоюватися практично, тобто в живому інтонуванні. Б. Асаф'єв писав: "3 інтонаційної точки зору, кожен інтервал досягається (усвідомлюється) слухом, і мелодія, по суті, є виявом інтервалів" [1, с. 218]. Учений зазначав, що "кожен інтервал закріплюється в музиці - завдяки передаванню життєвої практики - як носій емоційно-смислового тонусу, як інтонація, що сфрормувалася і закріпилася, як вокальна або інструментальна експресія, як резонанс відчуттів, які викарбувалися в даному постійному звуковідношенні" [1, с. 239].

Дотримуючись поглядів Б. Асаф'єва, Ю. Бичков пропонує інтервал секунди або терції подавати як побудований з них пісенний матеріал. Також теоретик наголошує на значущості виховання відчуття стійкості та нестійкості, оскільки поняття ладу містить поняття тоніки. Наприклад, такі поспівки можуть бути одним 3 "ембріонів" тональності.

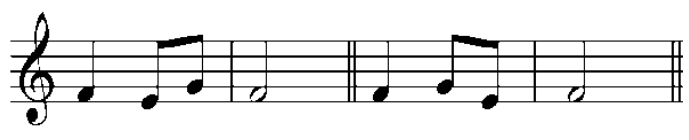

Із засвоєнням елементарних ладових звукорядів здійснюється засвоєння певного набору мелодичних поспівок. Так, музикознавець наводить приклади, де секундовий лад включає в себе чотири поспівки, терційний лад, відповідно, більше.

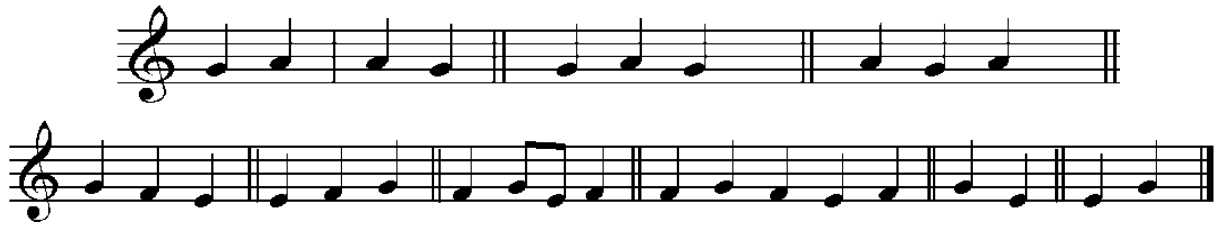

Ці мелодичні поспівки мають емоційно-смислову інтерпретацію. Емоційний заряд, який відчують учні під час співу матеріалу, дадуть можливість сфрормувати та розвинути інтонаційний слух. Саме він і буде слугувати одним з головних компонентів у процесі музично-інтонаційного мислення.

Безумовно, однією з важливих сторін методики виховання мелодичного слуху $€$ знакове фріксування звуковисотних співвідношень. Під час нотного запису часовий музичний образ перетворюється на просторовий образ. Музика починає засвою- 
ватись не тільки слухом, але й очами. Око починає брати участь у процесі слухання музики. Ю. Бичков пише, що "зорові образи здатні досягати динаміки мелодичного руху: через нотний запис до його сприймання підключаються зорові асоціації та емоційний досвід, пов'язаний з оцінкою руху в просторі... Виникає специфрічне підкріплення смислової сторони інтонування" [4, с. 53].

Отже, музичне-інтонаційне мислення ґрунтується на наявності мелодичного слуху (інтонаційного), внутрішніх уявленнях (внутрішньому слуху), досвіді, запасі слухових образів у пам'яті. Від розвинутості мелодичного слуху залежить рівень сфрормованості музично-інтонаційного мислення, яке дає можливість аналізувати, що чуєш, подумки уявляти та чути елементи музичної мови, читати та чути написану музику.

\section{Література}

1. Асафьев Б. В. Музыкальная форма как процесс / Б. В. Асафьев. - Л. : Музыка, 1971. - $376 \mathrm{c}$.

2. Афанасьєв Ю. Л. Професійна підготовка музиканта: уроки Болеслава Яворського / Ю. Л. Афранасьєв, Ф. О. Джура. - К. : ДАКККіМ, 2009. - 128 с.

3. Баевский В. С. Мировоззрение Яворского и некоторые тенденции советской культуры / В. С. Баевский // Советская музыка. - М. : Музыка, 1980. - С. 156-174.

4. Бычков Ю. Н. О ладовой настройке / Ю. Н. Бычков // Вопросы теории музыки. Труды ГМПИ им. Гнесиных / под ред. Т. Е. Лейе. - М. : ГМПИ им. Гнесиных, 1977. - № $30-$ C. $46-60$.

5. Давыдова Е. В. Методика преподавания сольфеджио / Е. В. Давыдова. - М. : Музыка, 1986. -160 c.

6. Робустова Л. О. О взаимодействии музыки и речи в процессе развития музыкального слуха и мышления (традиционный и современный подход к проблеме) / Л. О. Робустова // Традиции и новаторство в музыке : тезисы Межреспубликанской науч.теоретической конф., посвящённой 60-летию КазССР и КП Казахстана. - Алма-Ата, 1980. - C. 243-246.

7. Теплов Б. М. Психология музыкальных способностей / Б. М. Теплов. - М.-Л. : АПН РСФСР, 1947. $-335 \mathrm{c}$.

8. Цыпин Г. М. Обучение игре на фортепиано : учеб. пособие для студ. пед. ин.тов по спец. № 2119 "Музыка и пение" / Г.М.Цыпин. - М. : Просвещение, 1984. - 176 с.

9. Яворский Б. Л. Избранные труды / Б. Л. Яворский. - М. : Советский композитор, 1987.

T. 2, ч. 1. - 1987. -366 c.

10. Брайнин В. Б. Тени на стене, или Заметки о возможном подходе к развитию музыкального мышления у детей [Електронний ресурс] / В. Б. Брайнин. - Режим доступу: http://www.brainin.org/Method/Teni na stene.htm. - Назва з екрана. 